\title{
Persepsi Mahasiswa Terhadap Pembelajaran Biologi Molekuler Menggunakan Zoom Meeting Saat Pandemi Covid-19
}

\section{A. S. Alonemarera ${ }^{1 *}$}

1 Program Studi S-1 Pendidikan Biologi, Fakultas Keguruan dan Ilmu Pendidikan, Universitas Sembilanbelas November Kolaka, Indonesia

*Email: alonemarerausn@gmail.com

\begin{tabular}{|c|c|}
\hline Info Artikel & Abstrak \\
\hline $\begin{array}{l}\text { Diterima: } 2 \text { Juni } 2021 \\
\text { Direvisi: } 8 \text { Oktober } 2021 \\
\text { Diterima } \\
\text { untuk diterbitkan: } 23 \text { Oktober } \\
2021\end{array}$ & $\begin{array}{l}\text { Program studi pendidikan biologi, Universitas Sembilanbelas } \\
\text { November Kolaka, menjadi salah satu pelaksana pembelajaran } \\
\text { fully online akibat pandemi Covid-19. Zoom meeting } \\
\text { merupakan aplikasi yang sering digunakan dalam } \\
\text { melaksanakan pembelajaran online. Dosen pengampu mata }\end{array}$ \\
\hline $\begin{array}{l}\text { Keywords: } \\
\text { Biologi Molekuler, Pandemi } \\
\text { Covid-19, Persepsi Mahasiswa, } \\
\text { Zoom Meeting }\end{array}$ & $\begin{array}{l}\text { kuliah biologi molekuler menganggap aplikasi ini tepat } \\
\text { digunakan sebagai media pembelajaran berdasarkan } \\
\text { karakteristik yang dimiliki. Namun, pada mahasiswa sendiri } \\
\text { belum pernah dilakukan penilaian persepsi terkait penggunaan } \\
\text { zoom meeting. Oleh karena itu, penelitian ini bertujuan untuk } \\
\text { mengetahui persepsi mahasiswa terhadap penggunaan zoom } \\
\text { meeting pada mata kuliah biologi molekuler saat pandemi } \\
\text { Covid-19. Penelitian ini merupakan penelitian deskriptif yang } \\
\text { subjek penelitiannya seluruh mahasiswa kelas A angkatan } 2018 \\
\text { berjumlah } 27 \text { orang dan memprogram mata kuliah biologi } \\
\text { molekuler pada semester genap tahun akademik 2020/2021. } \\
\text { Data penelitian dikumpulkan melalui penyebaran angket online } \\
\text { kepada mahasiswa dalam bentuk google form. Angket online } \\
\text { berisi } 6 \text { buah pernyataan dengan } 5 \text { pilihan jawaban. Setiap } \\
\text { pernyataan disediakan kolom pemberian alasan responden atas } \\
\text { pilihan jawaban. Hasil penelitian menunjukkan } 15 \% \\
\text { mahasiswa sangat setuju, } 49 \% \text { mahasiswa setuju, } 23 \% \\
\text { mahasiswa memilih ragu-ragu, } 12 \% \text { mahasiswa memilih opsi } \\
\text { tidak setuju, dan } 1 \% \text { mahasiswa memilih sangat tidak setuju. } \\
\text { Mahasiswa yang memiliki opsi sangat setuju dan setuju } \\
\text { umumnya berpendapat bahwa melalui aplikasi zoom meeting } \\
\text { dosen dan mahasiswa tetap dapat bertatap muka meskipun } \\
\text { berbeda tempat. Adapun mahasiswa dengan opsi ragu-ragu, } \\
\text { tidak setuju, dan sangat tidak setuju umumnya beralasan bahwa } \\
\text { jaringan internet di daerah tempat tinggal mereka kurang } \\
\text { mendukung. Disarankan agar penggunaan aplikasi }\end{array}$ \\
\hline
\end{tabular}


zoom meeting yang bersifat sinkronus dipadukan dengan aplikasi atau media pembelajaran lain yang bersifat asinkronus untuk membantu mahasiswa yang terkendala jaringan.

(C) 2021 Universitas Bengkulu. This is an open-access article under the CC-BY license (https://creativecommons.org/licenses/by/4.0)

\section{PENDAHULUAN}

Sejak tanggal 11 Maret 2020, WHO sebagai organisasi kesehatan dunia telah mendeklarasikan bahwa Corona virus disease, yang disingkat Covid-19 dan ditemukan pada tahun 2019, telah mengalami penyebaran dan dikategorikan sebagai pandemi global. Virus yang berasal dari kawasan Wuhan, Cina, tersebut dengan cepat menular dan menyebar ke seluruh belahan dunia (Cucinotta \& Vanelli, 2020). Kondisi ini mengharuskan beberapa negara, termasuk Indonesia, menerapkan kebijakan karantina mandiri bagi warganya guna memutus rantai penyebaran Covid19. Pembatasan aktivitas warga di luar rumah membawa dampak pada berbagai sektor, salah satunya sektor pendidikan. Data dari UNESCO menyebutkan, bahwa sebanyak 39 negara saat ini telah memberlakukan penutupan sekolah. Negara-negara di Eropa, Amerika Tengah, Amerika Selatan, Timur Tengah, Asia, dan Afrika hampir seluruhnya telah membatasi aktivitas pembelajaran di sekolah secara langsung (offline) dan beralih ke pembelajaran online (Purwanto dkk., 2020). Di Indonesia sendiri, pemerintah telah menginstruksikan agar seluruh lembaga pendidikan untuk sementara menerapkan model sistem pembelajaran online secara penuh (fully online model) guna mencegah dan menangani penyebaran Corona virus disease (Covid-19). Instruksi tersebut tertuang dalam surat Edaran Kemendikbud No. 2 Tahun 2020 dan No.3 Tahun 2020.

Universitas Sembilanbelas November Kolaka (USN Kolaka) sebagai salah satu perguruan tinggi negeri di Sulawesi Tenggara, turut memberlakukan fully online dalam praktik perkuliahan di setiap program studi. Hal ini sebagai upaya perguruan tinggi untuk menurunkan resiko dan melindungi seluruh civitas akademika dari penyebaran Covid-19. Proses perkuliahan yang sementara tidak dapat dilakukan melalui tatap muka langsung, mendorong dosen memilih berbagai aplikasi yang dinilai tepat, guna mendukung pelaksanaan pembelajaran jarak jauh. Salah satu aplikasi alternatif yang cukup familiar adalah zoom meeting.

Menurut Liu \& Ilyas (2020) aplikasi zoom memiliki fitur screen sharing yang dapat dimanfaatkan untuk melakukan meeting berbasis online. Aplikasi ini memberi ruang kepada penggunanya agar dapat bertatap muka langsung secara online dengan lebih dari 100 peserta. Penggunaan aplikasi zoom meeting tidak hanya terbatas pada laptop atau PC saja, namun juga dapat diunduh pada smartphone yang sebagian besar dimiliki oleh mahasiswa. Sedangkan menurut Monica \& Fitriawati (2020), kehadiran zoom meeting akan membantu pendidik dan peserta didik dalam pelaksanaan pembelajaran jarak jauh. Dengan adanya fasilitas video conference dari aplikasi zoom, pendidik dan peserta didik dapat melakukan interaksi tatap muka walaupun tidak berdekatan. Hal serupa ditegaskan oleh Chen et al. (2005) yang menggolongkan video conference dari zoom meeting sebagai synchronous learning yang bersifat real time. Interaksi antara pendidik dan peserta didik dapat terjadi pada waktu yang bersamaan walaupun berbeda tempat. Wibawanto (2020) menyebutkan zoom meeting sebagai media komunikasi jarak jauh melalui penggabungan video conference, chatting, online meeting, dan kolaborasi seluler sehingga selain sebagai upaya penerapan teknologi dalam pembelajaran, juga menjadi pendukung dalam pelaksanaan perkuliahan jarak jauh antara dosen dengan mahasiswa di masa pandemi Covid-19.

Salah satu mata kuliah yang menggunakan aplikasi zoom meeting adalah biologi molekuler. Sebagai bagian dari ranah ilmu biologi, biologi molekuler memiliki perkembangan yang sangat pesat. Hal ini terutama terjadi di negara-negara maju. Biologi molekuler membahas kehidupan pada skala molekul terutama interaksi molekul dalam benda hidup, seperti interaksi antara molekul DNA, RNA, dan sintesis protein di dalam sel. Menurut Yunus \& Syam (2021) dibutuhkan aplikasi yang menarik untuk mengajarkan biologi molekuler kepada mahasiswa guna membantu proses 
pemahamannya. Hal ini, karena materi yang dipelajari dalam biologi molekuler dinilai cukup kompleks dan rumit.

Berdasarkan karakteristik yang dimiliki aplikasi zoom meeting dalam uraian paragraf ke-3, maka dosen memilih aplikasi zoom meeting sebagai salah satu media bantu dalam melaksanakan praktik pengajaran biologi molekuler. Melalui penggunaan zoom meeting, diharapkan proses pembelajaran tetap berlangsung secara tatap muka dalam waktu yang bersamaan meski berbeda tempat. Melalui fitur screen sharing dari aplikasi zoom meeting, dosen dapat menampilkan tayangan materi kepada mahasiswa, misalnya yang disusun dalam bentuk power point, video animasi, atau bentuk-bentuk tayangan lain yang mendukung sambil memberikan penjelasan sehingga mahasiswa dapat melihat dan mendengar secara langsung. Jika terdapat hal yang kurang dipahami oleh mahasiswa, mereka dapat mengajukan pertanyaan dan dosen dapat segera memberi tanggapan. Dengan demikian, diharapkan komunikasi antar dosen dan mahasiswa selama proses pembelajaran biologi molekuler di masa pandemi Covid-19 dapat berjalan secara efektif. Menurut Lestari \& Maliki (2003) suatu komunikasi dapat dikatakan efektif jika komunikasi tersebut mengandung aliran informasi dua arah antar pelaku komunikasi, yakni komunikan dan komunikator, dimana informasi yang disampaikan tersebut sama-sama dapat direspon berdasarkan harapan masing-masing pelaku komunikasi.

Dalam perkuliahan, dosen sebagai komunikator dan mahasiswa sebagai komunikan, tentunya memiliki persepsi masing-masing terkait kondisi komunikasi yang telah atau sedang dilakukan, termasuk persepsi mengenai media komunikasi yang digunakan. Selama pandemi Covid-19, dosen pengampu mata kuliah biologi molekuler menganggap aplikasi zoom meeting tepat digunakan sebagai media pembelajaran berdasarkan karakteristik yang dimiliki oleh zoom meeting. Namun demikian, dibalik kelebihan aplikasi zoom meeting terdapat pula sisi kelemahan. Aplikasi zoom meeting yang penggunaannya berbasis internet, tentu sangat bergantung pada ketersediaan dan kekuatan sinyal internet. Ketiadaan dukungan internet yang baik akan membuat pengguna mengalami kesulitan dalam mengakses atau menjalankan aplikasi tersebut. Menurut Setyani (2021) koneksi sinyal internet yang tidak stabil menjadi keluhan mahasiswa ketika hendak mengikuti perkuliahan daring yang sifatnya langsung atau live.

Sebagai komunikan, mahasiswa pendidikan biologi yang memprogram mata kuliah biologi molekuler belum pernah dilakukan penilaian persepsi terkait penggunaan zoom meeting yang pada dasarnya memiliki aspek kelebihan dan kekurangan. Persepsi seorang pembelajar terhadap suatu proses pembelajaran memegang peranan yang sangat penting. Hasil penelitian Elfira dkk. (2018) menunjukkan bahwa antara persepsi dengan motivasi belajar terdapat keterkaitan yang sangat kuat, dimana menurut penelitian Ni'mah (2017) terdapat korelasi yang positif dan signifikan antara motivasi belajar dengan hasil belajar. Dengan demikian, dapat dikatakan bahwa hasil belajar mahasiswa dipengaruhi oleh persepsi sebagai salah satu faktornya. Meski melalui pembelajaran fully online di tengah pandemi Covid-19, diharapkan mahasiswa tetap mampu mencapai hasil belajar yang memuaskan pada mata kuliah biologi molekuler. Oleh karena itu, penulis menganggap perlu melakukan penelitian yang bertujuan untuk mengetahui persepsi mahasiswa terhadap penggunaan zoom meeting pada mata kuliah biologi molekuler saat pandemi Covid-19. Kedepannya, hasil penelitian ini akan menjadi salah satu bahan evaluasi terhadap pelaksanaan pembelajaran online pada mata kuliah biologi molekuler, serta penentuan upaya-upaya perbaikan jika dianggap perlu.

\section{METODE}

Penelitian ini merupakan penelitian deskriptif kualitatif yang dilakukan di Program Studi Pendidikan Biologi, Universitas Sembilanbelas November Kolaka, dimana peneliti sendiri selaku dosen pengampu mata kuliah biologi molekuler. Penelitian dilaksanakan pada bulan April hingga bulan Mei 2021. Adapun subjek penelitiannya adalah seluruh mahasiswa kelas A angkatan 2018 yang berjumlah 27 orang dan memprogram mata kuliah biologi molekuler pada semester genap tahun akademik 2020/2021. Data yang diperlukan dalam penelitian dikumpulkan menggunakan 
metode angket berupa penyebaran form angket online kepada mahasiswa melalui google form. Angket online tersebut berisi 6 buah pernyataan dengan 5 pilihan jawaban untuk setiap pernyataan, yakni sangat setuju (SS), setuju (S), ragu-ragu (RR), tidak setuju (TS), dan sangat tidak setuju (STS). Selain itu, juga disediakan kolom pemberian alasan responden atas pilihan jawaban dari setiap pernyataan. Angket tersebut merupakan hasil adaptasi dari angket penelitian Liu \& Ilyas (2020) dengan nilai validitas logis sebesar 4,2 yang berkategori valid menurut kategori validitas Hobri (2009). Sedangkan nilai reliabilitasnya sebesar 0,87 yang berkategori reliabel menurut kategori reliabilitas Sudjana (2009). Data hasil penyebaran angket kemudian diolah dan disajikan secara deskriptif.

\section{HASIL DAN PEMBAHASAN}

Data yang terhimpun mengenai persepsi mahasiswa terhadap pembelajaran biologi molekuler menggunaan zoom meeting saat pandemi Covid-19 disajikan dalam tabel 1 di bawah ini.

\section{Tabel 1}

Hasil Angket Persepsi Mahasiswa Terhadap Pembelajaran Biologi Molekuler Menggunakan Zoom Meeting Saat Pandemi Covid-19

\begin{tabular}{|c|c|c|c|}
\hline No & Pernyataan Angket Persepsi & $\begin{array}{c}\text { Persentase } \\
\text { Jawaban } \\
(\%) \\
\end{array}$ & Alasan \\
\hline \multirow[t]{14}{*}{1} & $\begin{array}{l}\text { Pembelajaran biologi molekuler online } \\
\text { menggunakan zoom meeting sangat membantu } \\
\text { dalam kegiatan pembelajaran di masa pandemi } \\
\text { Covid-19 }\end{array}$ & & \\
\hline & $\begin{array}{c}\text { Pilihan Jawaban } \\
\end{array}$ & & \\
\hline & Sangat Setuju & 33,3 & $\begin{array}{l}\text { Tidak berpotensi terpapar Covid- } \\
19\end{array}$ \\
\hline & & & $\begin{array}{l}\text { Dosen dan mahasiswa tetap } \\
\text { dapat bertatap muka secara } \\
\text { virtual }\end{array}$ \\
\hline & & & $\begin{array}{l}\text { Tepat digunakan untuk biologi } \\
\text { molekuler yang materinya dinilai } \\
\text { sulit }\end{array}$ \\
\hline & Setuju & 55,6 & $\begin{array}{l}\text { Tayangan dan penjelasan materi } \\
\text { dapat dilihat serta didengar } \\
\text { secara langsung }\end{array}$ \\
\hline & & & Membantu pemahaman materi \\
\hline & & & $\begin{array}{l}\text { Dosen dan mahasiswa dapat } \\
\text { berkomunikasi langsung }\end{array}$ \\
\hline & & & $\begin{array}{l}\text { Membantu mengefektifkan } \\
\text { pembelajaran }\end{array}$ \\
\hline & & & $\begin{array}{l}\text { Memfasilitasi terlaksananya } \\
\text { pembelajaran tatap muka }\end{array}$ \\
\hline & & & $\begin{array}{l}\text { Tepat digunakan untuk biologi } \\
\text { molekuler yang materinya dinilai } \\
\text { sulit }\end{array}$ \\
\hline & Ragu-ragu & 7,4 & $\begin{array}{lll}\text { Jaringan internet } & \text { kurang } \\
\text { mendukung } & & \\
\end{array}$ \\
\hline & Tidak Setuju & 3,7 & $\begin{array}{lll}\text { Jaringan internet kurang } \\
\text { mendukung }\end{array}$ \\
\hline & Sangat Tidak Setuju & 0,0 & \\
\hline 2 & 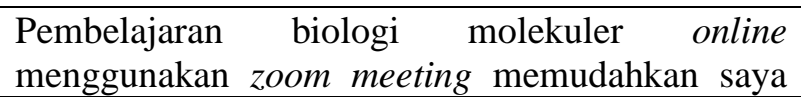 & & \\
\hline
\end{tabular}




\begin{tabular}{|c|c|c|c|}
\hline No & Pernyataan Angket Persepsi & \multirow[t]{2}{*}{$\begin{array}{c}\text { Persentase } \\
\text { Jawaban } \\
(\%)\end{array}$} & \multirow[t]{2}{*}{ Alasan } \\
\hline & $\begin{array}{l}\text { lengakses materi pembelajaran } \\
\text { Covid-19 }\end{array}$ & & \\
\hline \multicolumn{4}{|c|}{ Pilihan Jawaban } \\
\hline \multirow{2}{*}{\multicolumn{2}{|c|}{ Sangat Setuju }} & \multirow[t]{2}{*}{18,5} & $\begin{array}{l}\text { Tayangan dan penjelasan materi } \\
\text { dapat dilihat serta didengar } \\
\text { secara langsung }\end{array}$ \\
\hline & & & $\begin{array}{l}\text { Materi dapat diperoleh dengan } \\
\text { mudah melalui tautan yang } \\
\text { dishare melalui room chat }\end{array}$ \\
\hline \multirow{3}{*}{\multicolumn{2}{|c|}{ Setuju }} & \multirow[t]{3}{*}{51,9} & $\begin{array}{l}\text { Dapat mengajukan pertanyaan } \\
\text { langsung kepada dosen }\end{array}$ \\
\hline & & & $\begin{array}{l}\text { Mendapatkan penjelasan materi } \\
\text { yang diakses }\end{array}$ \\
\hline & & & $\begin{array}{l}\text { Memudahkan } \\
\text { dengan dosen untuk mengakses } \\
\text { materi }\end{array}$ \\
\hline \multirow{2}{*}{\multicolumn{2}{|c|}{ Ragu-ragu }} & \multirow[t]{2}{*}{18,5} & Terkadang jaringan tidak stabil \\
\hline & & & $\begin{array}{l}\text { Akses materi dari sumber lain } \\
\text { pun lebih mudah }\end{array}$ \\
\hline \multirow{2}{*}{\multicolumn{2}{|c|}{ Tidak Setuju }} & \multirow[t]{2}{*}{11,1} & Terkadang jaringan tidak stabil \\
\hline & & & $\begin{array}{l}\text { Masih bingung menggunakan } \\
\text { zoom meeting }\end{array}$ \\
\hline
\end{tabular}

3 Pembelajaran biologi molekuler online menggunakan zoom meeting dapat meningkatkan kualitas interaksi dan komunikasi saya dengan dosen selama pembelajaran di masa pandemi Covid-19

\begin{tabular}{|c|c|c|}
\hline Pilihan Jawaban & & \\
\hline \multirow[t]{2}{*}{ Sangat Setuju } & \multirow[t]{2}{*}{11,1} & $\begin{array}{l}\text { Lebih aktif dan percaya diri } \\
\text { menjawab pertanyaan dosen } \\
\text { yang biasanya gugup ketika } \\
\text { kuliah offline }\end{array}$ \\
\hline & & $\begin{array}{l}\text { Lebih percaya diri mengajukan } \\
\text { pertanyaan kepada dosen }\end{array}$ \\
\hline \multirow[t]{2}{*}{ Setuju } & \multirow[t]{2}{*}{37,0} & $\begin{array}{l}\text { Dapat bertatap muka dan } \\
\text { berkomunikasi langsung dengan } \\
\text { dosen }\end{array}$ \\
\hline & & $\begin{array}{l}\text { Lebih percaya diri menjawab } \\
\text { pertanyaan yang biasanya malu } \\
\text { ketika kuliah offline }\end{array}$ \\
\hline \multirow[t]{2}{*}{ Ragu-ragu } & \multirow[t]{2}{*}{29,6} & Jaringan tidak mendukung \\
\hline & & $\begin{array}{l}\text { Terkadang tidak percaya diri } \\
\text { untuk menjawab pertanyaan } \\
\text { dosen }\end{array}$ \\
\hline \multirow[t]{2}{*}{ Tidak Setuju } & \multirow[t]{2}{*}{18,5} & Jaringan tidak mendukung \\
\hline & & Terbiasa pasif dalam perkuliahan \\
\hline Sangat Tidak Setuju & 3,7 & $\begin{array}{l}\text { Tetap merasa terbatasi secara } \\
\text { ruang dalam berkomunikasi } \\
\text { dibandingkan kuliah offline }\end{array}$ \\
\hline
\end{tabular}




\begin{tabular}{ccl}
\hline No Pernyataan Angket Persepsi & $\begin{array}{c}\text { Persentase } \\
\text { Jawaban } \\
(\mathbf{\%})\end{array}$ & \multicolumn{1}{c}{ Alasan } \\
\hline $\begin{array}{c}\text { pembelajaran biologi molekuler online di masa } \\
\text { pandemi Covid-19 }\end{array}$ & 7,4 & $\begin{array}{l}\text { Zoom meeting sangat familiar } \\
\text { dan sudah sering dimanfaatkan }\end{array}$ \\
\hline Pilihan Jawaban & 48,1 & $\begin{array}{l}\text { Fitur zoom meeting sangat } \\
\text { mudah digunakan }\end{array}$ \\
\hline Sangat Setuju & $\begin{array}{l}\text { Jaringan dan paket data sangat } \\
\text { mendukung }\end{array}$ \\
\hline Ragu-ragu & 25,9 & $\begin{array}{l}\text { Terkadang jaringan tidak } \\
\text { mendukung }\end{array}$ \\
\hline Tidak Setuju & 14,8 & $\begin{array}{l}\text { Jaringan tidak mendukung } \\
\text { Masih bingung menggunakan } \\
\text { zoom meeting }\end{array}$ \\
\hline Sangat Tidak Setuju & 3,7 & \begin{tabular}{l} 
Jaringan tidak mendukung \\
\hline
\end{tabular}
\end{tabular}

5 Penggunaan zoom meeting dapat meningkatkan kualitas proses pembelajaran biologi molekuler online di masa pandemi Covid-19

\begin{tabular}{|c|c|c|}
\hline \multicolumn{3}{|l|}{ Pilihan Jawaban } \\
\hline Sangat Setuju & 11,1 & $\begin{array}{l}\text { Zoom meeting merupakan salah } \\
\text { satu platform yang sangat tepat } \\
\text { digunakan selama perkuliaan } \\
\text { masa pandemi }\end{array}$ \\
\hline \multirow[t]{4}{*}{ Setuju } & \multirow[t]{4}{*}{48,1} & $\begin{array}{l}\text { Zoom meeting mendukung } \\
\text { perkuliahan tatap muka langsung } \\
\text { meski berjauhan fisik }\end{array}$ \\
\hline & & $\begin{array}{l}\text { Memudahkan penyampaian } \\
\text { materi oleh dosen }\end{array}$ \\
\hline & & $\begin{array}{l}\text { Zoom meeting memiliki fitur- } \\
\text { fitur yang sangat membantu } \\
\text { dalam proses perkuliahan }\end{array}$ \\
\hline & & $\begin{array}{l}\text { Tayangan dan penjelasan materi } \\
\text { dapat dilihat serta didengar } \\
\text { secara langsung }\end{array}$ \\
\hline \multirow[t]{4}{*}{ Ragu-ragu } & \multirow[t]{4}{*}{25,9} & $\begin{array}{l}\text { Membantu selama perkuliahan } \\
\text { masa pandemi namun tidak lebih } \\
\text { baik dari kuliah tatap muka } \\
\text { offline }\end{array}$ \\
\hline & & $\begin{array}{l}\text { Tergantung mahasiswanya, ada } \\
\text { yang kemampuan memahaminya } \\
\text { cepat dan ada pula yang lambat }\end{array}$ \\
\hline & & $\begin{array}{l}\text { Lebih memilih kuliah tatap muka } \\
\text { offline }\end{array}$ \\
\hline & & Terkadang jaringan tidak stabil \\
\hline \multirow[t]{3}{*}{ Tidak Setuju } & \multirow[t]{3}{*}{14,8} & Jaringan tidak mendukung \\
\hline & & $\begin{array}{l}\text { Banyak mahasiswa berlaku } \\
\text { curang selama perkuliahan } \\
\text { (sengaja menonaktifkan video } \\
\text { lalu melakukan aktivitas lain) }\end{array}$ \\
\hline & & $\begin{array}{l}\text { Tergantung mahasiswanya, ada } \\
\text { yang kemampuan memahaminya }\end{array}$ \\
\hline
\end{tabular}




\begin{tabular}{|c|c|c|c|}
\hline No & Pernyataan Angket Persepsi & $\begin{array}{c}\text { Persentase } \\
\text { Jawaban } \\
(\%)\end{array}$ & Alasan \\
\hline & & & cepat dan ada pula yang lambat \\
\hline & Sangat Tidak Setuju & 0,0 & \\
\hline \multirow[t]{13}{*}{6} & $\begin{array}{l}\text { Di masa pandemi Covid-19, penggunaan zoom } \\
\text { meeting dapat membantu saya memahami materi } \\
\text { pembelajaran biologi molekuler }\end{array}$ & & \\
\hline & Pilihan Jawaban & & \\
\hline & Sangat Setuju & 7,4 & $\begin{array}{l}\text { Tayangan dan penjelasan materi } \\
\text { dapat dilihat serta didengar } \\
\text { secara langsung }\end{array}$ \\
\hline & \multirow[t]{3}{*}{ Setuju } & \multirow[t]{3}{*}{$\overline{55,6}$} & $\begin{array}{l}\text { Tayangan dan penjelasan materi } \\
\text { dapat dilihat serta didengar } \\
\text { secara langsung }\end{array}$ \\
\hline & & & $\begin{array}{l}\text { Memahami materi lebih baik } \\
\text { karena terfokus ke suara dosen } \\
\text { dan terhindar dari suara berisik } \\
\text { teman-teman }\end{array}$ \\
\hline & & & $\begin{array}{l}\text { Penyajian materi sangat jelas } \\
\text { layaknya pembelajaran tatap } \\
\text { muka offline, hanya berbeda } \\
\text { tempat }\end{array}$ \\
\hline & \multirow[t]{4}{*}{ Ragu-ragu } & \multirow[t]{4}{*}{29,6} & Terkadang jaringan tidak stabil \\
\hline & & & $\begin{array}{l}\text { Menatap layar hp terlalu lama } \\
\text { membuat sakit kepala hingga } \\
\text { akhirnya hilang fokus }\end{array}$ \\
\hline & & & $\begin{array}{l}\text { Sulit untuk fokus memahami } \\
\text { materi melalui kuliah online }\end{array}$ \\
\hline & & & $\begin{array}{l}\text { Tetap kurang paham dengan } \\
\text { materi }\end{array}$ \\
\hline & \multirow[t]{2}{*}{ Tidak Setuju } & \multirow[t]{2}{*}{7,4} & $\begin{array}{l}\text { Tetap kurang paham dengan } \\
\text { materi }\end{array}$ \\
\hline & & & $\begin{array}{l}\text { Tergantung mahasiswanya, ada } \\
\text { yang kemampuan memahaminya } \\
\text { cepat dan ada pula yang lambat }\end{array}$ \\
\hline & Sangat Tidak Setuju & 0,0 & \\
\hline
\end{tabular}

Hasil yang diperoleh pada masing-masing pernyataan angket dalam tabel 1 adalah: Pernyataan 1, diperoleh sebesar 55,6\% mahasiswa setuju bahwa aplikasi zoom meeting sangat membantu mahasiswa dalam pembelajaran selama pandemi dengan alasan, di antaranya melalui zoom meeting tayangan dan penjelasan materi dari dosen dapat dilihat dan didengar oleh mahasiswa secara langsung, sedangkan 3,7\% mahasiswa memilih tidak setuju dengan alasan jaringan internet yang kurang mendukung. Salah satu fitur yang dimiliki oleh aplikasi zoom adalah video conference. Penggunaan video conference akan sangat bermanfaat jika pemakaiannya tepat (Hyder et al., 2007). Menurut Sasongko dkk. (2019) selama ada koneksi ke internet, video conference memungkinkan dilakukannya pembelajaran tatap muka secara virtual (virtual meeting) menggantikan pembelajaran tatap muka langsung di kelas. Di sisi lain, dengan adanya keharusan koneksi internet, maka kelancaran virtual meeting menjadi sangat bergantung pada kestabilan jaringan. Hal ini dipertegas oleh Harun (2020) bahwa salah satu kelemahan aplikasi zoom selain boros kuota adalah dinilai kurang aman karena sangat bergantung pada ketersediaan jaringan internet, sehingga ketika jaringan mengalami kendala maka penggunaan aplikasi zoom pun menjadi tidak efektif. 
Pernyataan 2, diperoleh sebesar 51,9\% mahasiswa setuju bahwa zoom meeting memberikan kemudahan dalam mengakses materi pembelajaran di masa pandemi dengan alasan, di antaranya mahasiswa dapat mendownload materi dari tautan yang dengan mudah dishare melalui room chat dari aplikasi zoom, sedangkan $11,1 \%$ mahasiswa memilih tidak setuju dengan alasan ketidakstabilan jaringan dalam mengakses materi atau masih adanya mahasiswa yang bingung dalam menggunakan aplikasi zoom meeting. Aplikasi zoom tidak hanya mampu menciptakan kondisi tatap muka secara virtual, namun juga memberi ruang bagi penggunanya untuk melakukan percakapan secara tertulis melalui fitur chatting yang dimiliki (Hidayatullah dkk., 2020). Melalui fitur chatting tersebut, dosen dapat membagikan link materi perkuliahan yang dapat diakses oleh mahasiswa. Namun, tidak dapat dipungkiri bahwa penggunaan zoom meeting menjadi sesuatu yang baru bagi sebagian mahasiswa yang selama ini melakukan pembelajaran langsung di kelas untuk kepentingan tatap muka. Terdapat mahasiswa yang masih bingung dalam penggunaan aplikasi zoom sehingga merasa sulit untuk mengakses materi yang dibagikan.

Pernyataan 3, diperoleh sebesar 37\% mahasiswa setuju bahwa penggunaan zoom meeting selama proses pembelajaran online berlangsung dapat memaksimalkan komunikasi dan interaksi dengan dosen. Diantara alasannya adalah mahasiswa dapat bertatap muka dan berkomunikasi langsung dengan dosen terkait pembahasan materi. Walaupun tidak berada pada satu tempat yang sama, menurut Sandiwarno (2016) idealnya suatu pembelajaran harus tetap mewadahi interaktifitas antara pendidik dan peserta didik. Pembelajaran tatap muka dapat terlaksana secara online dengan bantuan fitur video conference pada aplikasi zoom. Dengan demikian, pendidik dapat berinteraksi langsung dengan peserta didik. Namun, menurut Aulia Luqman Aziz, pakar pendidikan dari Universitas Brawijaya (UB), akhir-akhir ini telah banyak keluhan dari orang tua dan peserta didik mengenai pembelajaran fully online. Dalam keterangannya di laman resmi UB, yang bertepatan dengan Hari Pendidikan Nasional 2020, Aulia Luqman Aziz memaparkan bahwa hadirnya teknologi tidak akan pernah bisa menggantikan profesi dosen. Penelitian Dzulfikri (2021) menyebutkan bahwa beberapa mahasiswa ilmu komunikasi dan ilmu pemerintahan angkatan 20172019, Universitas Muhammadiyah Jember, menilai pembelajaran online tidak semaksimal kegiatan pembelajaran langsung di kelas. Hal tersebut sejalan dengan hasil penelitian ini, dimana ditemukan 3,7\% mahasiswa memilih opsi sangat tidak setuju atas penggunaan zoom meeting dalam perkuliahan online dengan alasan merasa terbatasi secara ruang dalam berkomunikasi dibandingkan kuliah offline. Dengan kata lain, mahasiswa tersebut lebih memilih kuliah tatap muka langsung secara offline dibandingkan secara online.

Pernyataan 4, diperoleh sebesar $48,1 \%$ mahasiswa setuju bahwa zoom meeting mudah digunakan dalam pembelajaran biologi molekuler di masa pandemi dengan alasan, di antaranya fitur-fitur zoom meeting sangat mudah digunakan, sedangkan 3,7\% mahasiswa memilih sangat tidak setuju dengan alasan jaringan yang tidak mendukung dalam menggunakan zoom meeting. Menurut Luhulima dkk. (2016) anak-anak jaman sekarang merupakan anak-anak generasi Z, yaitu mereka yang lahir pada periode dengan perkembangan teknologi yang begitu canggih. Sebagian dari mereka sudah terbiasa dengan gaya dan media komunikasi yang kekinian. Dengan memanfaatkan berbagai fitur dalam aplikasi zoom, mereka tetap mampu bersosialisasi dengan teman sekelas. (Hidayatullah dkk., 2020) menyebutkan fitur-fitur yang terdapat dalam aplikasi zoom adalah pertemuan/rapat one-on-one, rapat grup melalui video konferensi, sharing screen and chat, dan recording video call.

Pernyataan 5, diperoleh sebesar 48,1\% mahasiswa setuju bahwa zoom meeting dapat meningkatkan kualitas proses pembelajaran biologi molekuler online di masa pandemi Covid-19 dengan alasan, di antaranya zoom meeting mendukung dilaksanakannya perkuliahan tatap muka langsung meski berjauhan fisik, sedangkan $14,8 \%$ mahasiswa memilih tidak setuju dengan alasan diantaranya kondisi jaringan yang tidak mendukung atau adanya mahasiswa yang berlaku curang selama perkuliahan yang sengaja menonaktifkan video lalu melakukan aktivitas lain. Salah satu keunggulan pembelajaran zoom menurut Harun (2020) adalah adanya fitur on/off video yang memungkinkan penggunanya mengaktifkan atau menonaktifkan kamera laptop atau hp yang 
digunakan. Sayangnya, keunggulan ini kerap disalahgunakan oleh oknum mahasiswa yang tidak bertanggungjawab dengan sengaja mematikan kamera agar aktivitasnya tidak terpantau oleh dosen selama perkuliahan. Dengan demikian, kegiatan lain yang tidak berkaitan dengan perkuliahan dapat dilakukan dengan bebas.

Pernyataan 6, diperoleh sebesar 55,6\% mahasiswa setuju bahwa penggunaan zoom meeting dapat membantu dalam memahami materi pembelajaran biologi molekuler dengan alasan, di antaranya mahasiswa menjadi lebih fokus dalam pembelajaran karena benar-benar terpusat pada tayangan/suara/penjelasan dosen serta terhindar dari suara berisik teman-temannya, sedangkan 7,4\% mahasiswa memilih tidak setuju dengan alasan mahasiswa tetap kurang mampu memahami materi biologi molekuler sekalipun materi dijelaskan secara langsung melalui aplikasi zoom meeting. Disamping adanya fitur on/off video, zoom meeting juga memiliki fitur on/off audio/mikrofon. Sebelum perkuliahan dimulai, dosen dapat memberikan instruksi agar seluruh mahasiswa menonaktifkan mikrofon masing-masing selama penjelasan materi oleh dosen nantinya. Dengan demikian, kelas menjadi lebih tertib dan perhatian mahasiswa dapat terfokus pada materi perkuliahan. Menurut Monica \& Fitriawati (2020) salah satu cara untuk mencapai efektivitas pembelajaran adalah dengan memperhatikan kesesuaian situasi dan kondisi dengan jenis media pembelajaran yang digunakan, baik dari segi konten materi maupun keadaan lingkungan mahasiswa itu sendiri.

Adapun persentase secara umum terkait persepsi mahasiswa terhadap pembelajaran biologi molekuler menggunakan zoom meeting saat pandemi Covid-19 dapat dilihat pada gambar 1.

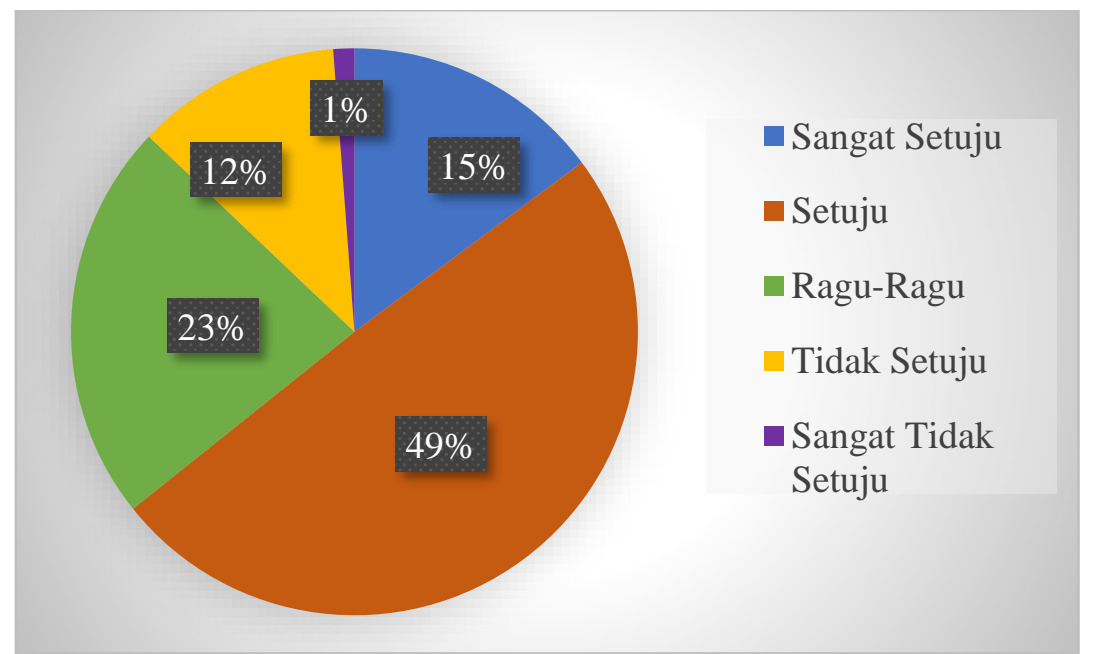

Gambar 1. Persepsi Mahasiswa Terhadap Pembelajaran Biologi Molekuler Menggunakan Zoom Meeting Saat Pandemi Covid-19

Berdasarkan gambar 1, sebanyak 15\% mahasiswa sangat setuju dan 49\% mahasiswa setuju atas penggunaan zoom meeting dalam pembelajaran biologi molekuler online saat pandemi Covid19. Sebanyak $23 \%$ mahasiswa memilih ragu-ragu, $12 \%$ mahasiswa memilih opsi tidak setuju, dan $1 \%$ mahasiswa memilih sangat tidak setuju. Bagi mahasiswa yang memilih opsi sangat setuju dan setuju umumnya berpendapat bahwa melalui aplikasi zoom meeting dosen dan mahasiswa tetap dapat bertatap muka secara langsung secara online di tempat yang berbeda sehingga tayangan dan penjelasan materi dosen selama perkuliahan berlangsung dapat dilihat dan didengar oleh mahasiswa layaknya perkuliahan offline di kelas. Adapun mahasiswa yang memilih opsi ragu-ragu, tidak setuju, dan sangat tidak setuju umumnya beralasan bahwa jaringan internet di daerah tempat tinggal mereka yang kurang mendukung. Di Provinsi Sulawesi Tenggara, masih banyak daerah yang kurang memperoleh jaringan internet. Hal ini diketahui dari data Badan Pusat Statistik (BPS) Provinsi Sulawesi Tenggara 2019 yang diambil dari hasil pendataan potensi desa tahun 2018. Gambaran kondisi jaringan internet pada kabupaten/kota yang tersebar di Provinsi Sulawesi Tenggara dapat dilihat pada tabel 2 di bawah ini. 


\section{Tabel 2}

Jumlah Desa/Kelurahan berdasarkan Keberadaan Base Transceiver Station (BTS), Sinyal Telepon Seluler, dan Sinyal Internet GSM atau CDMA di Sulawesi Tenggara Tahun 2018

\begin{tabular}{|c|c|c|c|c|c|c|c|c|c|c|}
\hline \multirow[b]{2}{*}{$\begin{array}{c}\text { Kabupaten/ } \\
\text { Kota }\end{array}$} & \multicolumn{2}{|c|}{$\begin{array}{c}\text { Keberadaan } \\
\text { BTS }\end{array}$} & \multicolumn{4}{|c|}{ Kekuatan sinyal telepon seluler } & \multicolumn{4}{|c|}{$\begin{array}{c}\text { Sinyal internet GSM atau } \\
\text { CDMA }\end{array}$} \\
\hline & Ada & $\begin{array}{l}\text { Tidak } \\
\text { ada }\end{array}$ & $\begin{array}{c}\text { Sangat } \\
\text { kuat }\end{array}$ & Kuat & Lemah & $\begin{array}{l}\text { Tidak } \\
\text { ada } \\
\text { sinyal }\end{array}$ & $\begin{array}{l}\text { 4G/ } \\
\text { LTE }\end{array}$ & $\begin{array}{c}3 G / \\
\mathbf{H} / \\
\mathbf{H}+\end{array}$ & $\begin{array}{l}\text { 2G/E/ } \\
\text { GPRS }\end{array}$ & $\begin{array}{c}\text { Tidak } \\
\text { Ada } \\
\text { Sinyal } \\
\text { Internet }\end{array}$ \\
\hline Kolaka Utara & 29 & 104 & 10 & 72 & 46 & 5 & 24 & 84 & 15 & 5 \\
\hline $\begin{array}{l}\text { Kolaka } \\
\text { Timur }\end{array}$ & 18 & 115 & 20 & 46 & 42 & 25 & 38 & 44 & 15 & 11 \\
\hline Kolaka & 39 & 96 & 33 & 79 & 21 & 2 & 55 & 61 & 8 & 9 \\
\hline Konawe & 49 & 322 & 64 & 208 & 69 & 30 & 812 & 177 & 24 & 12 \\
\hline Muna Barat & 15 & 71 & 12 & 35 & 39 & - & 17 & 32 & 31 & 6 \\
\hline $\begin{array}{l}\text { Buton } \\
\text { Selatan }\end{array}$ & 14 & 56 & 27 & 23 & 19 & 1 & 33 & 29 & 1 & 6 \\
\hline Kota Baubau & 24 & 19 & 8 & 29 & 6 & - & 26 & 17 & - & - \\
\hline Kota Kendari & 49 & 16 & 40 & 22 & 3 & - & 48 & 14 & 1 & 2 \\
\hline Bombana & 32 & 111 & 23 & 46 & 53 & 21 & 36 & 41 & 18 & 27 \\
\hline Buton & 27 & 68 & 22 & 34 & 28 & 11 & 10 & 31 & 33 & 10 \\
\hline $\begin{array}{l}\text { Buton } \\
\text { Tengah }\end{array}$ & 23 & 54 & 9 & 29 & 38 & 1 & 14 & 39 & 23 & - \\
\hline Buton Utara & 8 & 83 & 12 & 30 & 45 & 4 & 24 & 44 & 4 & 15 \\
\hline $\begin{array}{l}\text { Konawe } \\
\text { Utara }\end{array}$ & 9 & 164 & 12 & 63 & 73 & 25 & 29 & 65 & 6 & 48 \\
\hline $\begin{array}{l}\text { Konawe } \\
\text { Kepulauan }\end{array}$ & 13 & 83 & 10 & 19 & 44 & 23 & 13 & 8 & 8 & 44 \\
\hline $\begin{array}{l}\text { Konawe } \\
\text { Selatan }\end{array}$ & 64 & 293 & 47 & $\begin{array}{c}16 \\
6\end{array}$ & 134 & 10 & 84 & 222 & 23 & 18 \\
\hline Wakatobi & 24 & 76 & 10 & 69 & 20 & 1 & 33 & 47 & 12 & 7 \\
\hline Muna & 41 & 145 & 39 & 98 & 45 & 4 & 39 & 113 & 12 & 18 \\
\hline $\begin{array}{l}\text { Sulawesi } \\
\text { Tenggara }\end{array}$ & 478 & 1876 & 398 & 6810 & 725 & 163 & 165 & $\begin{array}{c}106 \\
8\end{array}$ & 234 & 823 \\
\hline
\end{tabular}

Sumber: Badan Pusat Statistik (BPS) Provinsi Sulawesi Tenggara 2019

Tabel 2 menunjukkan ketersediaan jaringan internet di Provinsi Sulawesi Tenggara belum merata. Hal ini tentunya menjadi kendala atau hambatan tersendiri terhadap kelancaran pembelajaran biologi online bagi sebagian mahasiswa, khususnya pada mata kuliah biologi molekuler saat pandemi Covid-19 seperti sekarang ini. Mahasiswa kelas A angkatan 2018 yang berjumlah 27 orang dan memprogram mata kuliah biologi molekuler pada semester genap tahun akademik 2020/2021 mayoritas berasal dari kabupaten/kota yang berada di area Provinsi Sulawesi Tenggara. Berdasarkan biodata mahasiswa yang telah dihimpun, diketahui sebanyak 11 orang (41\%) mahasiswa berasal dari Kabupaten Kolaka, 5 orang (19\%) dari Kabupaten Buton Tengah, 5 orang (19\%) dari Kabupaten Kolaka Timur, 2 orang (7\%) dari Kabupaten Kolaka Utara, 2 orang (7\%) dari Kabupaten Buton dan 1 orang (4\%) dari Kabupaten Bombana, Sulawesi Tenggara. Adapun 1 orang (4\%) berasal dari luar Sulawesi Tenggara, yakni Kabupaten Banggai, Provinsi Sulawesi Tengah.

Data dalam tabel 2 menunjukkan bahwa di daerah Kabupaten Buton, Buton Tengah, Bombana, Kolaka Timur, Kolaka Utara, dan bahkan Kolaka sendiri sebagai lokasi pusat kampus USN, masih ditemukan adanya desa/kelurahan yang tidak terjangkau oleh sinyal internet. Kalaupun ada, kekuatan sinyalnya masih lemah. Sementara menurut Iskandarsjah \& Murdaningsih (2020) untuk menjalankan aplikasi zoom meeting, dibutuhkan dukungan jaringan internet yang baik/stabil agar penggunaan fitur-fitur aplikasi zoom seperti webcam video dan screen sharing dapat berjalan 
lancar. Dengan demikian, mahasiswa-mahasiswa yang berada pada lokasi dengan kondisi sinyal yang kurang mendukung akan mengalami kendala atau hambatan dalam mengikuti perkuliahan online, khususnya pada mata kuliah biologi molekuler, saat pandemi Covid-19 ini. Solusi yang dapat ditempuh oleh dosen guna membantu mahasiswa yang mengalami kendala sinyal menurut Setyani (2021) adalah dengan merekam jalannya pembelajaran live tersebut atau membuat video presentasi materi menggunakan aplikasi video recorder seperti web launch recorder, camtasia, maupun aplikasi perekam video lainnya yang dikuasai. Selanjutnya, video rekaman tersebut diunggah pada suatu platform pembelajaran yang bersifat asinkronus seperti google classroom, edmodo, maupun aplikasi lainnya yang relevan. Dengan kata lain, guna menunjang pelaksanaan pembelajaran biologi molekuler online, maka penggunaan aplikasi zoom meeting yang bersifat sinkronus perlu dipadukan dengan penggunaan aplikasi atau media pembelajaran lain yang bersifat asinkronus seperti google classroom, edmodo, maupun aplikasi/media lainnya yang relevan. Pembelajaran sinkronus merupakan pembelajaran yang interaksi antara pengajar dan pebelajarnya berlangsung pada waktu yang bersamaan melalui teknologi telekonferensi, sedangkan pembelajaran asinkronus merupakan pembelajaran dimana interaksi antara pengajar dan pebelajar tidak harus dalam waktu yang sama atau bersifat fleksibel (Fahlevi, 2021).

\section{KESIMPULAN}

Persepsi mahasiswa terhadap penggunaan zoom meeting pada mata kuliah biologi molekuler saat pandemi Covid-19 adalah sebanyak 15\% mahasiswa sangat setuju, 49\% mahasiswa setuju, $23 \%$ mahasiswa memilih ragu-ragu, 12\% mahasiswa memilih opsi tidak setuju, dan 1\% mahasiswa memilih sangat tidak setuju. Bagi mahasiswa yang memilih opsi sangat setuju dan setuju umumnya berpendapat, bahwa melalui aplikasi zoom meeting dosen dan mahasiswa tetap dapat bertatap muka secara langsung secara online di tempat yang berbeda sehingga tayangan dan penjelasan materi dosen selama perkuliahan berlangsung dapat dilihat dan didengar oleh mahasiswa layaknya perkuliahan offline di kelas. Adapun mahasiswa yang memilih opsi ragu-ragu, tidak setuju dan sangat tidak setuju umumnya beralasan bahwa jaringan internet di daerah tempat tinggal mereka yang kurang mendukung. Guna menunjang pelaksanaan pembelajaran biologi molekuler online, maka penggunaan aplikasi zoom meeting yang bersifat sinkronus perlu dipadukan dengan penggunaan aplikasi atau media pembelajaran lain yang bersifat asinkronus seperti google classroom, edmodo, maupun aplikasi/media lainnya yang relevan.

\section{DAFTAR PUSTAKA}

BPS Provinsi Sultra. (2019). Banyaknya Desa/Kelurahan Menurut Keberadaan Base Transceiver Station (BTS), Sinyal Telepon Seluler, dan Sinyal Internet GSM Atau CDMA, 2018. Retrieved from https://sultra.bps.go.id/statictable/2019/01/07/1372/banyaknya-desakelurahan-menurutkeberadaan base-transceiver-station-bts-sinyal-telepon-seluler-dansinyal-internet-gsm-ataucdma-2018.html.

Chen, N. S., Ko, H. C., Kinshuk, \& Lin, T. (2005). A model for synchronous learning using the internet. Innovations in Education and Teaching International, 42(2), 181-194. https://doi.org/10.1080/14703290500062599.

Cucinotta, D. \& Vanelli, M. (2020). WHO Declares Covid-19 a Pandemic. Acta Biomedica, 91(1), 157-160. doi: 10.23750/abm.v91i1.9397.

Dzulfikri, A. F., (2021). Evaluasi Efektivitas Kuliah Dalam Jaringan (daring) atau Kuliah Online pada Masa Pandemi Covid-19 (Studi Kasus Mahasiswa Ilmu Komunikasi dan Ilmu Pemerintahan Angkatan 2017-2019 Universitas Muhammadiyah Jember) (skripsi tidak dipublikasikan), Universitas Muhammadiyah Jember, Indonesia. 
Elfira, E., Warneri, \& Okianna. (2018). Hubungan Persepsi Belajar Dengan Motivasi Belajar Mata Pelajaran Ekonomi Siswa SMA Santun Untan Pontianak. Jurnal Pendidikan dan $\begin{array}{lllll}\text { Pembelajaran } \quad \text { Khatulistiwa, } & 7 & \text { (7). } & \text { (-8. }\end{array}$ (https://jurnal.untan.ac.id/index.php/jpdpb/article/view/26096, diakses 05 Maret 2021).

Fahlevi, F. (2021). Pengamat Pendidikan: Pembelajaran Online Harus Padukan Sinkronus dan Asinkronus. Retrieved from https://www.tribunnews.com/pendidikan/2021/04/25/pengamat-pendidikanpembelajaran-online-harus-padukan-sinkronus-dan-asinkronus.

Harun, M. (2020). Evaluasi Kualitas Perangkat Lunak Pada Aplikasi Zoom Cloud Meetings Untuk Pembelajaran E-learning. Jurnal Akrab Juara, 5 (3), 102-112. (online). https://akrab juara.com/index.php/akrabjuara/article/view/1210, diakses 28 Februari 2021).

Hidayatullah, S., Khouroh, U., Windhyastiti, I., Patalo, R. G., \& Waris, A. (2020). Implementasi Model Kesuksesan Sistem Informasi Delone And Mclean Terhadap Sistem Pembelajaran Berbasis Aplikasi Zoom Di Saat Pandemi Covid-19. Jurnal Teknologi dan Manajemen Informatika, 6 (1). 44-52. doi: https://doi.org/10.26905/jtmi.v6i1.4165.

Hobri. (2009). Metodologi Penelitian Pengembangan (Developmental Research) (Aplikasi pada Penelitian Pendidikan Matematika). Jember: FKIP Universitas Jember.

Hyder, K., Kwinn, A., Miazga, R., \& Murray, M. (2007). The eLearning Guild's Handbook on Synchronous e-Learning. Retrieved from https://www.learningguild.com /pdf/4/synchronousbook.pdf.

Iskandarsjah, E. \& Murdaningsih, D. (2020). Tips Atasi Gangguan Saat Video Conference Dengan Zoom. Retrieved from https://republika.co.id/berita/q7p4ki368/tips-atasi-gangguan-saatvideo-conference-dengan-zoom.

Lestari G.E. \& Maliki, M.A. (2003). Komunikasi Yang Efektif. Jakarta: Lembaga Administrasi Negara.

Liu, A. N. A. \& Ilyas. (2020). Persepsi mahasiswa dalam implementasi pembelajaran online berbasis zoom cloud meeting program studi pendidikan fisika Universitas Flores. $\begin{array}{llll}\text { Optika: Jurnal Pendidikan } & \text { Fisika, } 4 \text { 85-90. }\end{array}$ doi: https://doi.org/10.37478/optika.v4i2.689.

Luhulima, D. A., Degeng, I. N. S., \& Ulfa, S. (2016). Pembelajaran berbasis video untuk anak generasi Z. Prosiding Inovasi Pendidikan di Era Big Data dan Aspek Psikologinya. Retrieved

fromhttp://digilib.mercubuana.ac.id/manager/t! @file_artikel_abstrak/Isi_Artikel_31384 7955984. pdf, diakses 03 Maret 2021).

Monica, J \& Fitriawati, D. (2020). Efektivitas Penggunaan Aplikasi Zoom Sebagai Media Pembelajaran Online Pada Mahasiswa Saat Pandemi Covid-19. Jurnal Communio: $\begin{array}{lllll}\text { Jurnal Ilmu } & \text { Komunikasi, } & 9 & \text { (2). }\end{array}$ doi: https://doi.org/10.35508/jikom.v9i2.2416.

Ni'mah, U. (2017). Hubungan Minat dan Motivasi Belajar Dengan Hasil Belajar IPS Kelas V SDN Gugus Pangeran Diponegoro Kabupaten Pati (skripsi tidak dipublikasikan), Universitas Negeri Semarang, Indonesia. 
Purwanto, A., Pramono, R., Asbari, M., Hyun, C. C., Wijayanti, L. M., Putri, R. S., \& Santoso, P. B. (2020). Studi Eksploratif Dampak Pandemi Covid-19 Terhadap Proses Pembelajaran Online Di Sekolah Dasar. EduPsyCounts: Journal of Education, Phsycology, and Counselling, 2(1), $2716 \quad 4446 . \quad$ (online). (https://ummaspul.ejournal.id/Edupsycouns/article/view/397, diakses 02 Maret 2021).

Sandiwarno, S. (2016). Perancangan Model E-Learning Berbasis Collaborative Video Conference Learning Guna Mendapatkan Hasil Pembelajaran Yang Efektif dan Efisien. Jurnal

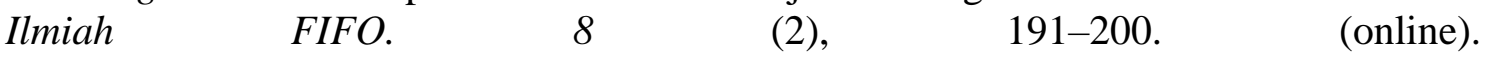
(https://publikasi.mercubuana.ac.id/index.php/fifo/article/view/ 1314/1011, diakses 28 Februari 2021).

Sasongko, D. B., Fatirul, N., \& Hartono. (2019). Pengembangan E-Learning Dengan Video Conference Untuk Pendukung Pembelajaran Informatika Terapan di Politeknik Kelautan dan Perikanan Sidoarjo. Jurnal Education and Development, 7(2), 236-240. doi: https://doi.org/10.37081/ed.v7i2.1001.

Setyani. R. A. (2021). Fenomena Pembelajaran Daring Perguruan Tinggi di Era Pandemi Covid19, Antara Dilema dan Realita. Retrieved from https://www.krjogja.com/angkringan/opini/ fenomena-pembelajaran-daring-perguruantinggi-di-era-pandemi-covid-19-antara-dilema-dan-realita/.

Sudjana, N. (2009). Penilaian Proses Hasil Belajar Mengajar. Bandung: Remaja Rosdakarya.

Wibawanto, T. (2020). Pemanfaatan Video Conference Dalam Pembelajaran Tatap Muka Jarak Jauh Dalam Rangka Belajar Dari Rumah. Retrieved from http://lpmplampung.kemdikbud.go.id/po-content/uploads/Artikel_VICON_Wibi_1.pdf.

Yunus, N. M. \& Syam, S. (2021). Efektivitas Perkuliahan Online Menggunakan Google Classroom Pada Mata Kuliah Biologi Molekuler. Biogenerasi: Jurnal Pendidikan Biologi, 6 (1), 31-36. (online). (https://e-journal.my.id/biogenerasi/article/view/512, diakses 22 Februari 2021). 